\title{
Developing a New Approach WAE to Research at Soba, the Capital of the Medieval Kingdom of Alwa
}

\author{
Mariusz Drzewiecki (D), Polish Centre of Mediterranean Archaeology, University of \\ Warsaw, Nowy Świat 4, 00-497, Warsaw, Poland \\ E-mail: mario517@wp.pl \\ Robert Ryndziewicz $\mathbb{D}$, Institute of Archaeology and Ethnology, Polish Academy of \\ Sciences, Warsaw, Poland
}

\begin{abstract}
Soba was the capital of one of the medieval kingdoms of Sahelian Africa. The remains are located on the right bank of the Blue Nile, approximately $15 \mathrm{~km}$ from Khartoum's downtown. It was the power centre for Nubian rulers of the Kingdom of Alwa, directly comparable to the main cities of the two other Nubian kingdoms, Nobadia and Makuria. Archaeological research has demonstrated that the metropolitan cities of Nobadia and Makuria had exceptional churches, monasteries, pottery production sites, areas with various buildings and fine houses as well as fortifications. In the case of Soba, the identification of an ecclesiastical complex of considerable size, unique finds and brief descriptions by medieval Arab historians suggest that it was also a highly diverse and complex settlement. In the last 20-30 years, large parts of Soba have rapidly been overbuilt. A tarmac road was laid across the northern part of the site and subsequent urbanisation covered approximately half of the 275 ha area of the capital city. Medieval architectural remains are not visible on the surface, but previous surveys identified at least seventeen mounds covered with red brick debris, and numerous mounds covered with gravel. Up to the present day, approximately $1 \%$ of medieval Soba has been researched in detail. As a result, not much is known about the spatial organisation of the city. In the search for a new approach which will enable sufficient protection, study and management of the site, two visits to Soba were made in 2018. The first in order to check the potential of geophysical prospection, and the second to initiate community outreach activities. With promising results, the project has received funding for 3 years from the National Science Centre in Poland and support from the National Corporation for Antiquities and Museums and Neelain University.
\end{abstract}


Résumé: Soba était la capitale de l'un des royaumes médiévaux de l'Afrique du Sahel. Ses vestiges se trouvent sur la rive droite du Nil bleu, à environ $15 \mathrm{~km}$ du centre de Khartoum. Elle constituait le centre du pouvoir pour les dignitaires nubiens du Royaume d'Alwa, et se comparait directement aux villes principales des deux autres royaumes nubiens, Nobadia et Makuria. La recherche archéologique a démontré que les villes métropolitaines de Nobadia et de Makuria étaient dotées d'églises exceptionnelles, de monastères, de sites de production de poterie, de quartiers comportant de nombreux immeubles et de belles demeures ainsi que des fortifications. Dans le cas de Soba, l'identification d'un ensemble ecclésiastique d'une taille considérable, les découvertes uniques ainsi que les brèves descriptions par des historiens arabes médiévaux suggèrent qu'il s'agissait également d'une implantation complexe et extrêmement diversifiée. Au cours des 20 à 30 dernières années, de grandes parties de Soba ont rapidement été saturées en termes de construction. Une route de bitume a été construite à travers la partie nord du site et l'urbanisation qui a suivi a couvert environ la moitié de la zone de 275 hectares de la capitale. Les vestiges architecturaux médiévaux ne sont pas visibles à la surface mais des études précédentes ont identifié au minimum dix-sept monticules couverts de débris de brique rouge et de nombreux monticules couverts de gravier. Jusqu'à l'époque présente, environ $1 \%$ de la Soba médiévale a fait l'objet d'une étude détaillée. II en résulte que fort peu est connu quant à l'organisation spatiale de la ville. En 2018, deux visites de Soba ont été effectuées dans le cadre d'une recherche pour une nouvelle approche qui permettra une protection suffisante, une étude et une gestion du site. La première avait vocation à vérifier le potentiel d'une prospection géophysique et la seconde visait à initier des activités de prise de contact avec la communauté. Les résultats prometteurs du projet ont permis l'octroi d'un financement sur trois ans accordé par le National Science Centre en Pologne ainsi que le soutien de la National Corporation for Antiquities and Museums et de I'Université Neelain.

Resumen: Soba fue la capital de uno de los reinos medievales del África saheliana. Los restos se encuentran en la orilla derecha del Nilo Azul, a unos $15 \mathrm{~km}$ del centro de Jartum. Fue el centro de poder para los gobernantes nubios del Reino de Alwa, directamente comparable a las principales ciudades de los otros dos reinos nubios, Nobadia y Makuria. La investigación arqueológica ha demostrado que las ciudades metropolitanas de Nobadia y Makuria tenían iglesias, monasterios, sitios de producción de cerámica, áreas con varios edificios y casas finas excepcionales, así como 
fortificaciones. En el caso de Soba, la identificación de un complejo eclesiástico de tamaño considerable, hallazgos únicos y breves descripciones de historiadores árabes medievales sugiere que también fue un asentamiento muy diverso y complejo. En los últimos 20-30 años, grandes partes de Soba se han construido en exceso rápidamente. Se colocó un camino asfaltado en la parte norte del sitio y la subsiguiente urbanización cubrió aproximadamente la mitad del área de 275 ha de la ciudad capital. Los restos arquitectónicos medievales no son visibles en la superficie, pero estudios anteriores identificaron al menos diecisiete montículos cubiertos con escombros de ladrillo rojo, y numerosos montículos cubiertos con grava. Hasta ahora, aproximadamente el $1 \%$ de la Soba medieval se ha investigado en detalle. Como resultado, no se sabe mucho sobre la organización espacial de la ciudad. En la búsqueda de un nuevo enfoque que permita la protección, el estudio y la gestión suficientes del sitio, se realizaron dos visitas a Soba en 2018. La primera para verificar el potencial de la prospección geofísica y la segunda para iniciar actividades de extensión comunitaria. Con resultados prometedores, el proyecto ha recibido fondos durante tres años del Centro Nacional de Ciencias en Polonia y el apoyo de la Corporación Nacional de Antigüedades y Museos y de la Universidad de Neelain.

\section{KEY WORDS}

Nubia, Spatial organisation, Geophysical prospection, Community outreaching activities

\section{Soba in Archaeological Narrations}

In archaeological narrations, Soba is presented as an important and at the same time unique place. It was the capital of the medieval kingdom of Alwa (approx. 6th-16th century), and it is one of the main archaeological sites in Nubia. In this context, a striking fact is that Soba lies far beyond the modern borders of Nubia. The ruins of the city are on the right bank of the Blue Nile, approximately $20 \mathrm{~km}$ from the confluence of White and Blue Niles in Central Sudan (Figure 1).

The site lies on a gently undulating plain intersected by a number of shallow watercourses. Easy to build on, Soba and its surroundings are now an agglomeration of Khartoum and a part of the largest conurbation in Sudan. In the past, long before Khartoum was established, Soba was a seat 


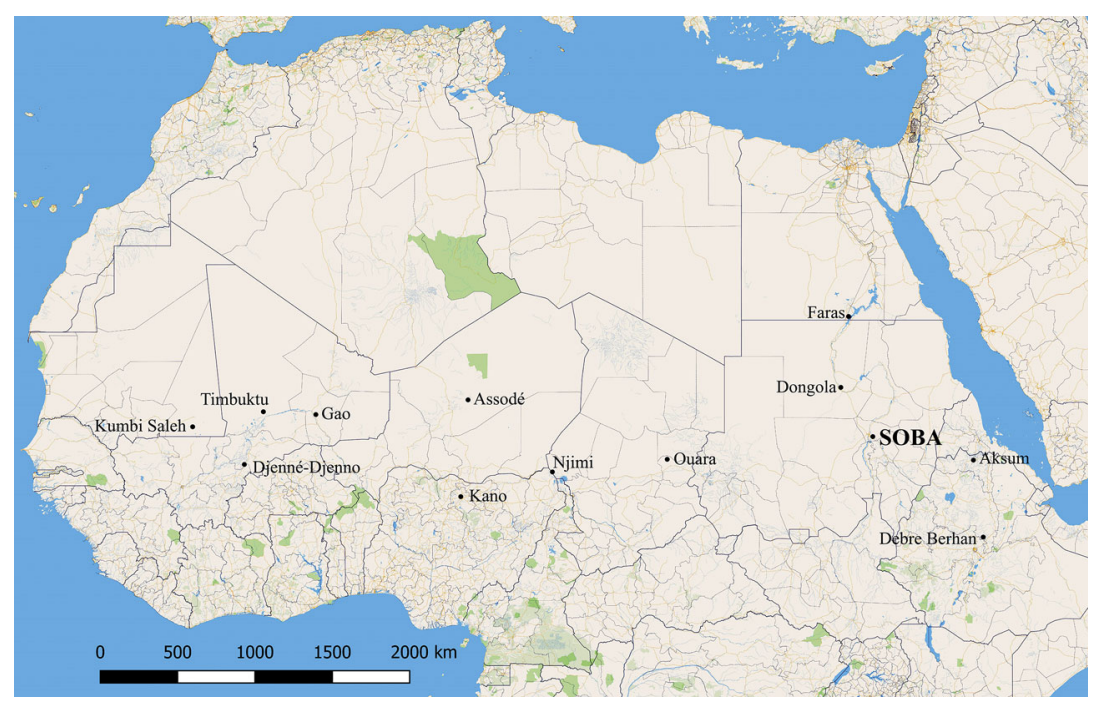

Figure 1. Location of Soba (prepared by Mariusz Drzewiecki; background image Wikimedia Commons)

of a royal family as well as the administrative and religious centre of the realm. Remains of the capital city are badly preserved, since in the 19th century, bricks from the ruins of Soba were used in the construction of numerous buildings in Khartoum. The estimated size of the site is between 240 ha and 275 ha.

To date, extensive excavations have uncovered only a small part of the site (Budge 1907; Somers Clarke 1912: 34-38; Shinnie 1961; Welsby and Daniels 1991; Welsby 1998; Abdel Rahman 2000), giving detailed information on selected buildings and activities inside the city, as well as identifying an ecclesiastical complex of considerable size.

Twentieth-century archaeological research indicates that the foundation of Soba as a major urban settlement should be dated to the late post-Meroitic period (5th-6th century AD). Only a few Meroitic finds suggest lack of substantial earlier settlement on the site (Welsby and Daniels 1991: 33). The largest development of the city took place between the 6th and 11th century. The 13th century witnessed the last activities on site, which have left distinguishable archaeological traces.

Large quantities of fine and unique artefacts, as well as monumental architecture, discovered during excavations, have given an insight into the city's wealth and far-reaching contacts. Written sources indicate that Soba hosted visitors from the Mediterranean region and the Ethiopian highlands. In its heyday, Soba was described by the Arab diplomat-traveller Ibn Selim el-Aswani in the following words: "It has fine buildings and large 
monasteries, churches rich with gold and gardens; there is also a great suburb where many Muslim live" (Vantini 1975: 613).

Soba attracted travellers and merchants from various parts of Africa and the Middle East, since already in medieval times it was recognised as the capital of the largest Nubian kingdom. Ibn Selim el-Aswani wrote that "The king of Alwa is more powerful than the king of Maqurra, has a larger army and more horses than the Maqurran: his country is more fertile and larger..." (Vantini 1975: 613).

High-quality local products, such as Soba ware pottery, were noticed and identified in various parts of the city. However, kilns and workshops where the vessels were made remain to be recognised. Derek Welsby suggested the presence of metal workshops in the capital (areas MN3 and MN8) on the northwestern outskirts of the city (Welsby 1998: 21). A kiln was recorded on kom B next to one of the largest buildings recorded on site (building D-Welsby and Daniels 1991: 105-106). No other production area/s were identified. Was there an industrial district/s in the city manufacturing local luxury and everyday items? The issue remains open.

Among the finds from one of the churches was a Greek stela recording a hitherto unknown king, David (Welsby 2004: 228-237). To date, the names of six kings of Alwa are attested in written sources. Neither their burials nor their palaces have been identified. Only small cemeteries were recognised in close proximity to the churches. Currently, the location of large burial grounds, for the common people, has not yet been established.

A few inscriptions recently discovered at Soba have started to broaden our understanding of Nubian dialect, which at Soba was apparently slightly different to the languages used by people from Makuria and Nobadia, the northern neighbouring Nubian kingdoms (van Gerven Oei 2018: 109; Łajtar, personal communication).

The findings support the exceptional status of the city; however, they provide little information on the general layout and organisation of the town itself. Mapping of the surface finds did not help clarify the matter either. The capital fell into ruin at the end of Medieval period and buildings were dismantled. Today, the architectural remains are not visible on the ground, with the exception of areas which have already been excavated (Figure 2). The surface of the site is, however, covered with numerous artificial mounds (koms) of various size, some with red brick debris.

Other capital cities of medieval Nubian kingdoms (Faras and Old Dongola) were recognised by archaeologists as large urban centres with exceptional churches, monasteries, pottery production sites, areas densely overbuilt with various buildings and fine houses, fortifications and in the case of Old Dongola a palatial complex. Soba is a comparable site, but its spatial organisation, division into various districts and suburbs still remain little understood. 


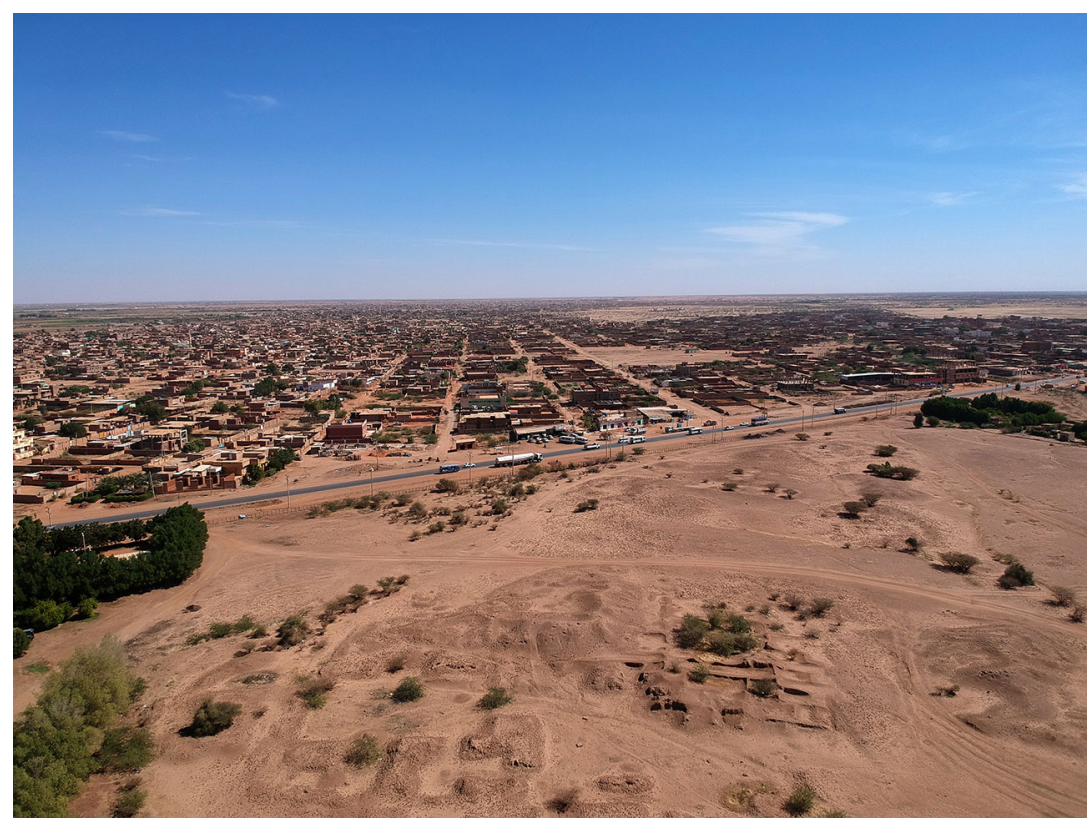

Figure 2. Aerial view of the northern part of the site with British excavations at the bottom, tarmac road in the middle and modern urbanisation in the background (photo Malaz Abdalfatah Fadalalseed)

\section{Previous Research in Soba}

Soba developed under Alwan rule. Results of archaeological research suggest that the city was in decline already in the 13th century. According to the Funj Chronicle and Abdallab tradition, the capital was destroyed at the beginning of 16th century. David Reubeni, a traveller, visited the place in 1523 and saw it in ruins (Hillelson 1933: 56, 60).

Early travellers left brief descriptions suggesting the great archaeological potential of the site. Frederic Cailliaud visited Soba in 1821 and gave firsthand information about a stone statue of a ram and stone columns protruding from the sand (Cailliaud 1826, II: 206). In the 19th century, Soba was a quarry for construction materials to build Khartoum, a new capital at the confluence of the Niles (Lepsius 1853: 162-163, 1913, V: 347). Large quantities of red brick were extracted and piled waiting to be shipped on the bank of the river. That is how it has been seen by Karl Richard Lepsius.

In the second part of the 19th century, the ruins became a place of interest for Khartoum-based foreign residents. The first to conduct excava- 


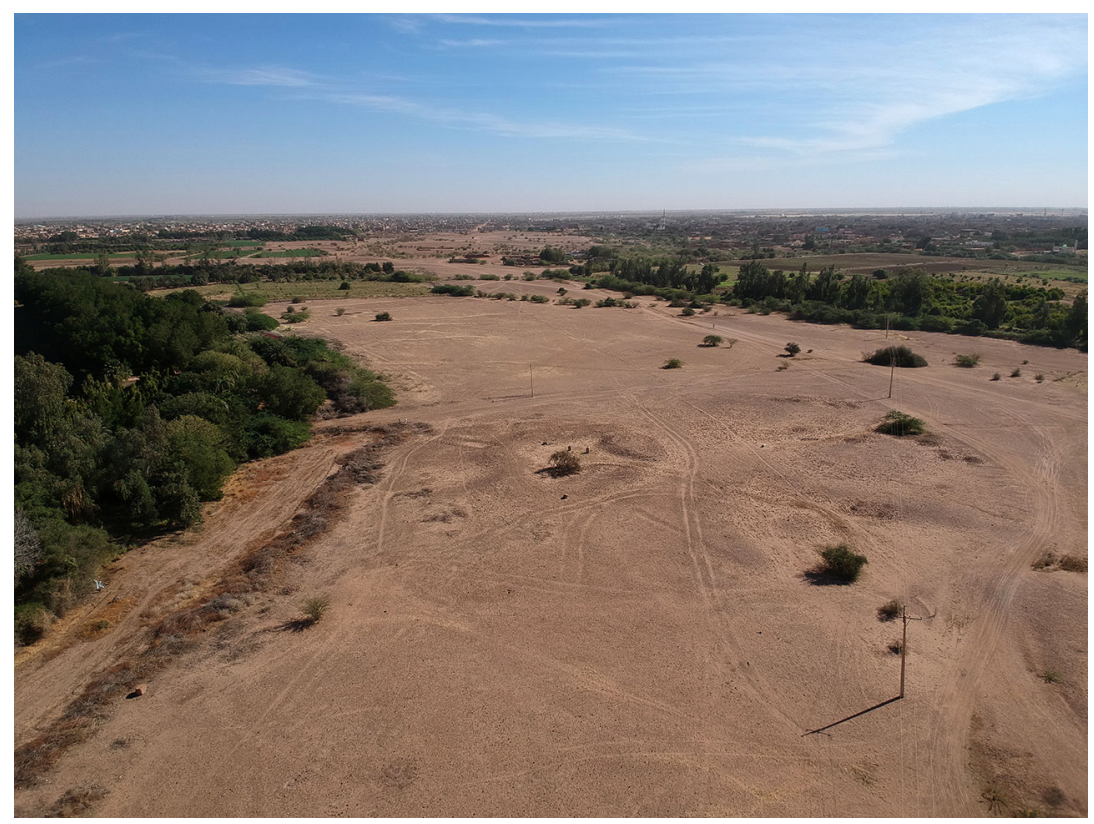

Figure 3. Aerial view of the southern part of the site, with stone columns protruding from the ground (photo Malaz Abdalfatah Fadalalseed)

tions there was Sieur de Bono in 1861, who cleared the earth around the pedestal of the statue of the ram (Lejean 1865: 25). Before 1885, General Charles Gordon brought the ram statue to Khartoum (Shinnie 1961: 17). Later, limited excavations in various parts of the site were carried out by Dümichen (1894: Taf. VI), Colonel E.A. Stanton (Ward 1905: 12-14) and Budge (1907, I: 325).

The first systematic excavations were undertaken by Somers Clarke (1912: 34-38), who documented the remains of the church with columns (Figure 3). In the 1930s, Soba was visited by Ugo Monneret de Villard. He made the first plan of the area, marking 20 mounds and naming four of them with capital letters, from A to D (Monneret de Villard 1935, I: 269 271; II: TAV. XCIX, C). His plan shows the magnitude of the site, however, it provides limited information on the spatial organisation of the city.

Between 1950-2, the Sudan Antiquities Service conducted research in the church with columns and investigated several other areas of the site. The team, directed by Peter Shinnie, made cross sections through the biggest mounds-kom A and B-and discovered the remains of mud brick and red brick architecture. Shinnie stated that there were around 100 mounds on the site. He published a general plan of the site and aerial pho- 
tographs estimating that the archaeological remains covered approximately 240 ha (Shinnie 1961: Plate I and map at the end of the book).

The longest regular survey and excavations at Soba began in 1981. They were directed by D.A. Welsby (excavations) and C.M. Daniels (survey). Results were published in a monograph in 1991 (Welsby and Daniels 1991). Three churches and a large building were discovered (Welsby 1998: 20). While the discoveries were crucial to the history of North Eastern Africa, the state of preservation of the monuments and artefacts was poor. Most of the red brick structures were preserved as negatives, since the building material was taken more than a century before and many layers were disturbed in the process.

In 1989-92, the work was continued by D.A. Welsby and published in articles and a monograph (Welsby 1998). Excavations, including salvage activities, were conducted in various parts of the site and yielded evidence for stone, timber, mud brick and red brick architecture. The remains of the capital identified up until the 1990s covered, according to Welsby, approx. 275 ha (Welsby 2002: 120). He recorded seventeen to twenty-nine mounds covered with red brick, and numerous mounds covered with gravel. After the end of the project, archaeological research on the site was suspended.

With the end of British involvement in the field research at Soba, the Sudan Antiquities Service and later the National Corporation for Antiquities and Museums of Sudan (NCAM) conducted only rescue excavations at the site. In 1992, prior to the construction of the el-Gereif East-Eilafoun road, NCAM discovered a cluster of ten graves, including one with a vaulted chamber (Abdel Rahman Ali Mohamed 2000: 27). In 2012, before the construction of the bridge across the Blue Nile, one mound was excavated uncovering the remains of a complex mud brick structure (Figure 4). The results of the fieldwork have not yet been published, but the bridge construction site had been shifted upriver to avoid disturbing antiquities (Abdelhai Abdelsawi, personal comment).

Since the beginning of research in Soba, in total, four red brick mounds have been extensively excavated. A few gravel mounds were tested, revealing that they cover the remains of mud brick and timber architecture. During C.M. Daniels survey, surface cleanings were conducted to reach the top of the architectural remains in several parts of the site (Welsby and Daniels 1991: 12-25). Budge (1907, I: 325) found a stone gateway, which constituted part of a fortification; however, the 1980s research by D.A. Welsby and C.M. Daniels did not record any traces of a defensive wall around the site or in any part of it.

In 1998, Derek Welsby concluded that since the beginning of the research in Soba, approximately $1 \%$ of the site had been studied in detail (Welsby 1998: 21). Research carried out later by the Sudan authorities, 


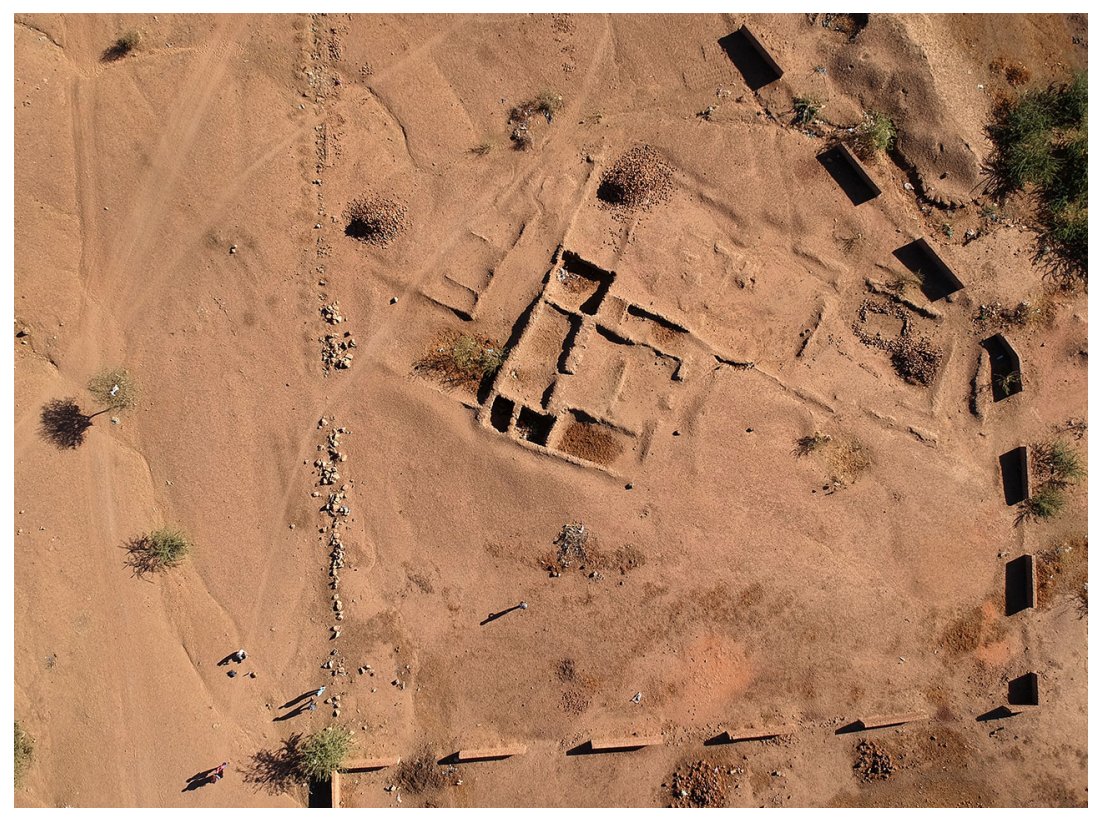

Figure 4. Mud brick architecture uncovered during National Corporation for Antiquities and Museums of Sudan rescue excavations in Soba (photo Mohammed Rageb Nolwata Islind)

while very important, did not increase this statistic to any significant extent.

On the other hand, modern urbanisation has not spared Soba. Every year, more houses are built in the area. The construction of the tarmac road in the 1990s and subsequent urbanisation had a large impact on the site, resulting in the reduction in the protected area from 275 ha to approx. 114 ha. Today, however, only approximately 53 ha remain untouched and are still available for a more thorough investigation.

The region has been rapidly changing in the last 20-30 years, from being a remote suburb of Khartoum, suitable for rest houses and orchards Soba is now densely urbanised with red brick industries developing on the bank of the Nile. In these new circumstances, the undeveloped land of the archaeological site is attracting the attention of local landowners. 


\section{Developing a New Approach}

\section{Geophysical Prospection and Aerial Photography}

The traditional technique of excavation, while providing valuable insights into many aspects of life in the medieval capital of Alwa did not significantly increase our knowledge about its spatial organisation. Surface surveys, cleanings and mapping, while delivering some information, remain difficult to interpret. The mounds are visible markers of ruined buildings and complexes but no complete architectural remains protrude from the ground. Only debris such as red bricks, mud bricks and small finds can be spotted on the surface. Based on such scarce information, it is difficult to build a strategy for the protection and management of the site, especially with accelerating development in the region (Figure 5). If no action is taken to protect it, soon the rest of Soba will be affected by modernisation.

In these circumstances, a new approach needs to be developed. Since medieval architectural remains are just below the sandy surface of the site, the most reasonable method for their identification is a geophysical survey. However, this method has never been used in Soba. Before launching a

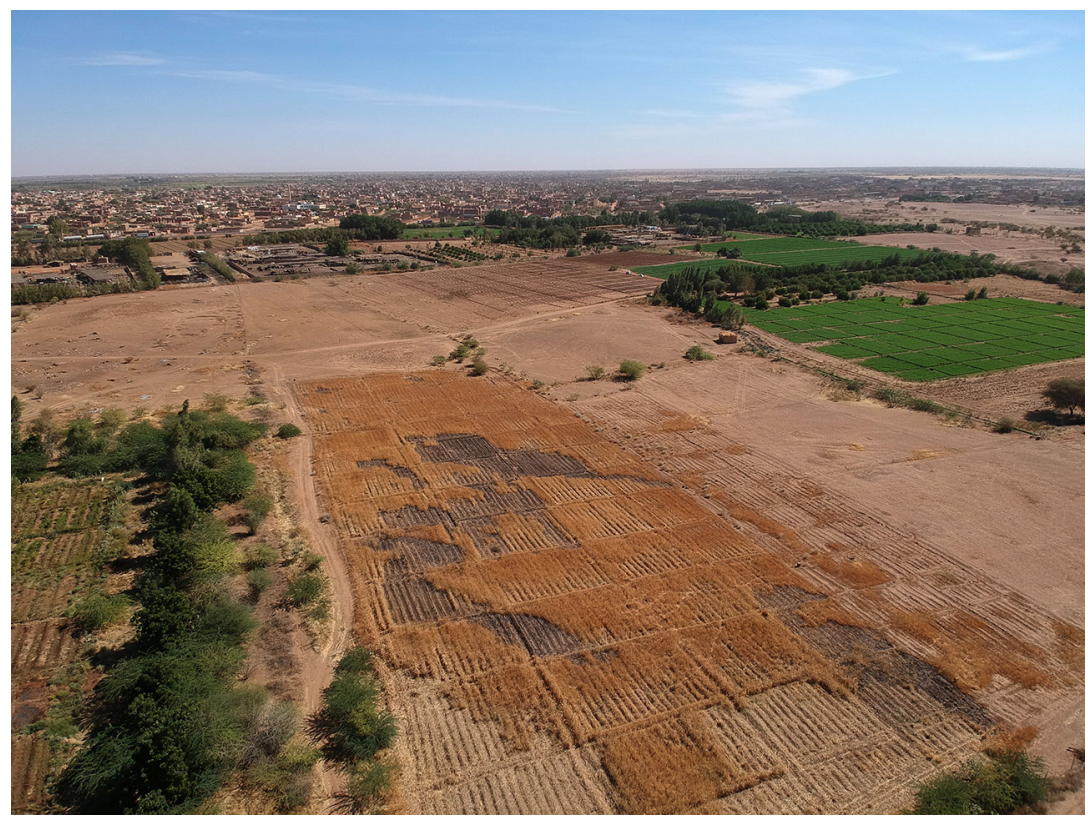

Figure 5. Modern activities at Soba (photo Mokhtar Maali Alden Mokhtar Hassan) 
large-scale project, it was essential to confirm that the method is suitable for the local conditions.

In January 2018, with the approval of Dr Abdelrahman Ali Mohammed (General Director of the NCAM), initial research was conducted in Soba by the authors (Drzewiecki and Ryndziewicz 2018: 33-34).

For the geophysical measurements, magnetometry was chosen as the most suitable for an initial survey. As an expeditious and non-invasive method, magnetometry offers effective way to collect the data and is able to detect and identify a wide assortment of archaeological features (David et al. 2008: 20-21). Due to the magnetic properties of alluvial Nile sediments, the magnetic method is highly effective in surveying the archaeological remains in Sudan and Egypt (Herbich 2019: 197).

A small area $(80 \times 40 \mathrm{~m})$ was selected for geophysical test-measurements (Figure 6). The area included the top of one of the mounds, its slopes and the surrounding flat terrain. No medieval architectural features were visible on the surface of the study area, a common situation in Soba. A Geoscan Research FM 256 fluxgate gradiometer was used to measure the gradient of the vertical component of the Earth's magnetic field with a resolution of $0.1 \mathrm{nT}$. Measurements were taken with a sampling density of

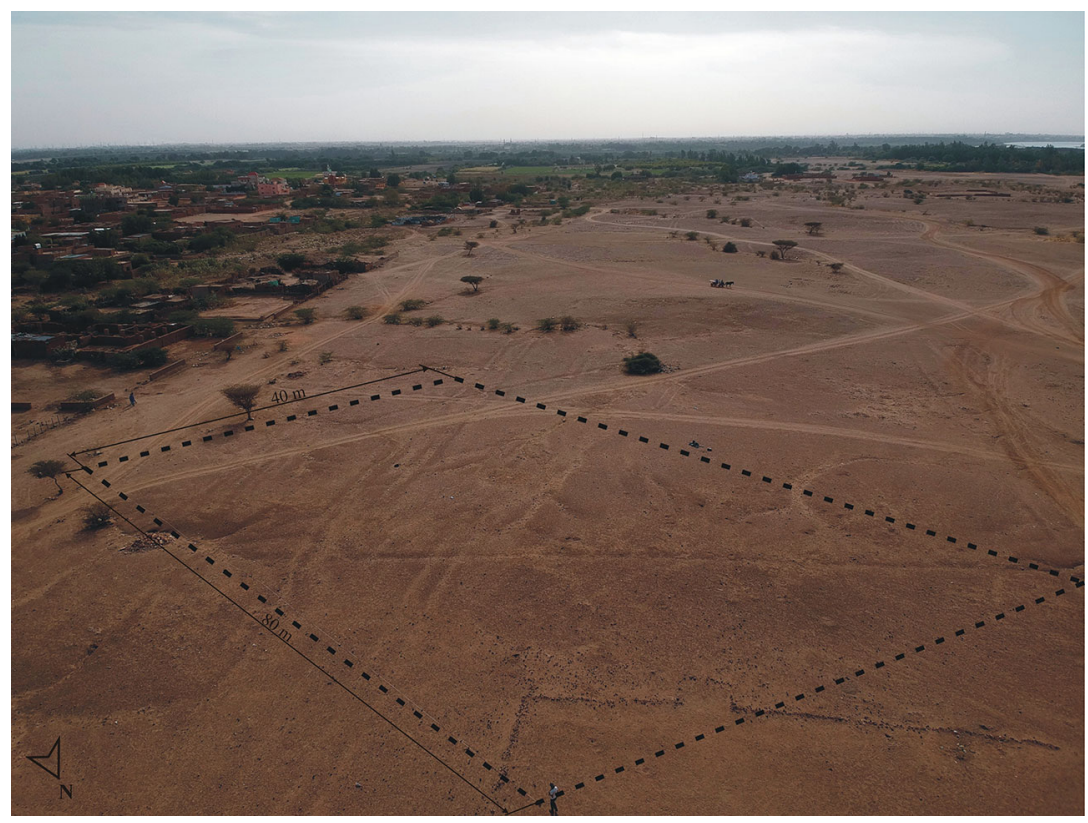

Figure 6. Rectangle marks the area chosen for geophysical testing (photo Mariusz Drzewiecki) 
a

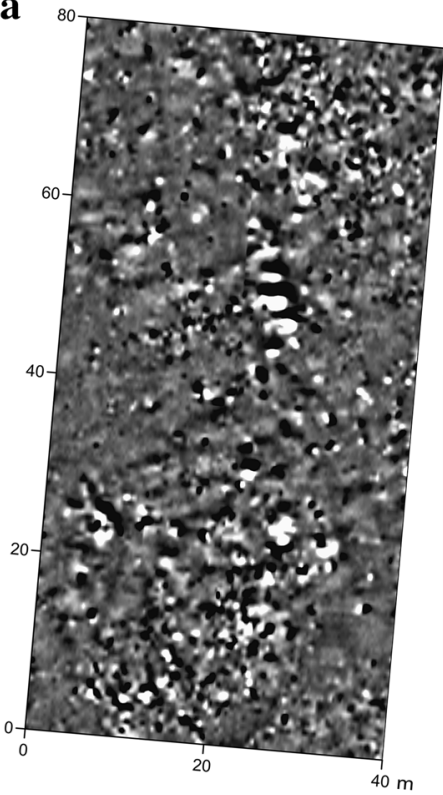

b

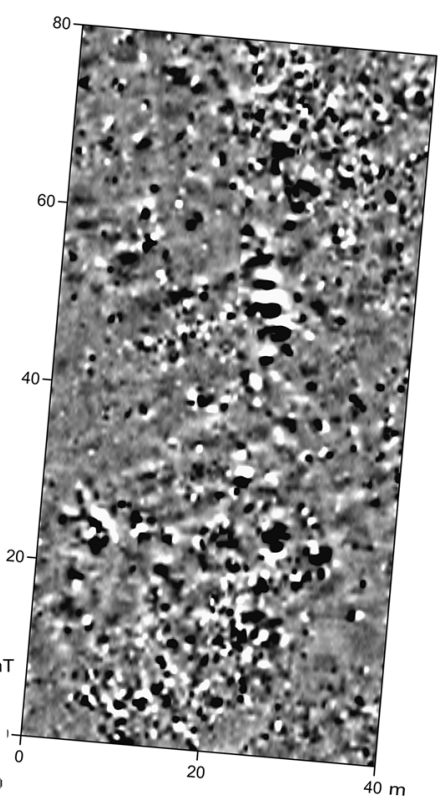

Figure 7. Results of the geophysical test conducted in January 2018. Map of the gradient of the vertical component of the Earth's magnetic field. Gradiometer Geoscan Research FM256. Sampling grid $0.25 \times 0.5 \mathrm{~m}$, interpolated. Dynamics: a) 4/+ 8 nT black/white, b) $-5 /+5 n T$ white/black (prepared by Robert Ryndziewicz)

eight readings per $1 \mathrm{~m}^{2}$ (every $0.25 \mathrm{~m}$ along profiles $0.5 \mathrm{~m}$ apart) within the $20 \times 20$ m grid.

To visualise the result, a grey-scale plotmap was created (Figure 7). Geoscan Research Geoplot 3.0 software was used to elaborate the data, following the essential set of processing techniques. Despike algorithm was used to minimise the influence of possible small iron detritus. The inaccurate positioning of particular profiles due to the use of zigzag mode was adjusted by the Destagger function. Zero Mean Traverse, Interpolation (to $0.25 \times 0.25 \mathrm{~m}$ ) and Low-Pass Filter were applied to normalise the contrast and smooth the appearance of anomalies. The resulting image shows various types of linear and dot-shaped anomalies that can be interpreted as a geophysical reflection of remains of urban structures.

To understand the nature of particular geophysical anomalies, we considered the results of other magnetic surveys, done at a larger scale in the Middle Nile Valley, particularly at Meroe (Mohamed Ali et al. 2012) and Hamadab (Ullrich and Wolf 2015). Although those projects do not concern medieval settlements, the geomorphological conditions and building materials were similar. The explanation of the relationship between anoma- 


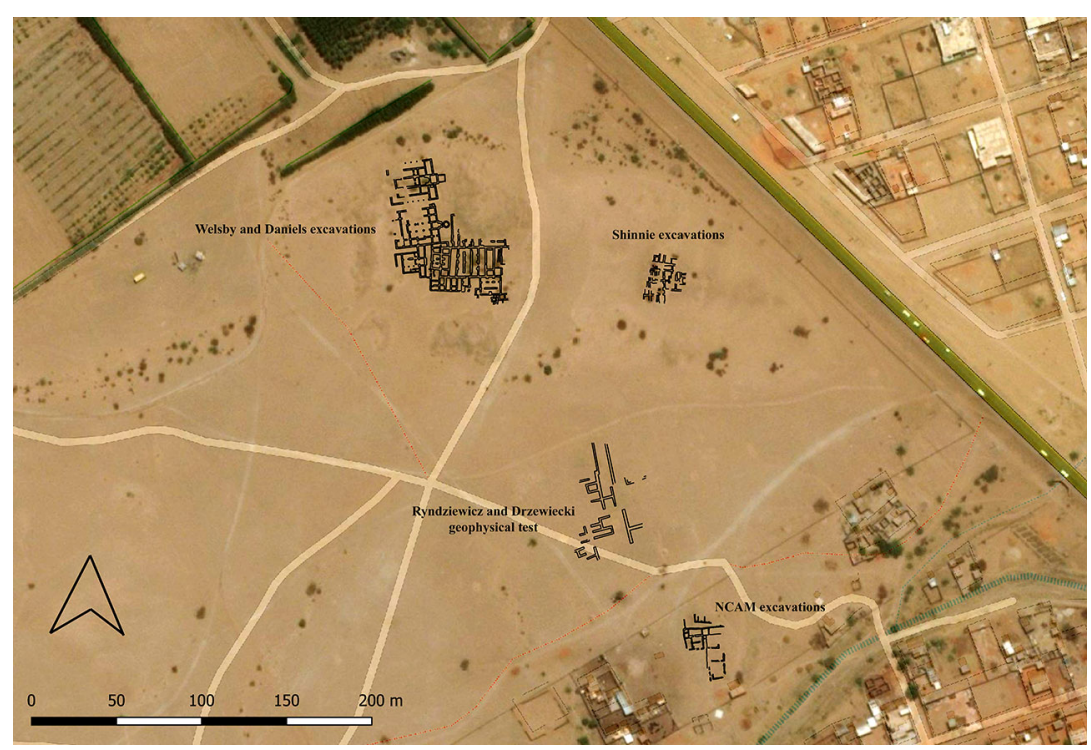

Figure 8. Plan of architectural remains on kom B and its surroundings documented during all fieldwork (prepared by Mariusz Drzewiecki, background image Google Earth and Open Street Map)

lies measured and buried structures is based also on the archaeological features and findings known from the excavations carried out at Soba in the past. According to the results of the excavations, most of the buildings in Soba were constructed of mud brick (Welsby and Daniels 1991: 26). Red brick walls were preserved in a poor condition, and most of them were recorded as negatives since the bricks had been removed. Also many disturbed layers and concentrations of scattered red brick debris were recorded in the course of the excavations (Welsby and Daniels 1991: 29).

Magnetic imagery shows regular, low amplitude, linear anomalies that can reflect mud brick walls. These potential walls are slightly angled from the magnetic north. Similar orientation of buildings was observed in some of the architectural remains discovered by Welsby and Daniels on kom B (Figure 8). A high level of noise was recorded across most of the study area, probably due to unstructured red brick debris just below the surface. Excavations in Soba delivered material related to metalworking (Freestone and Stapleton 1998: 81). Based on this evidence, it might be estimated that some spots of large, high-amplitude anomalies are connected with ash deposits or slag. Heavily burnt material may cause anomalies similar to iron fragments. Because of this, any definitive interpretation of the anomalies is not possible without further investigation. 


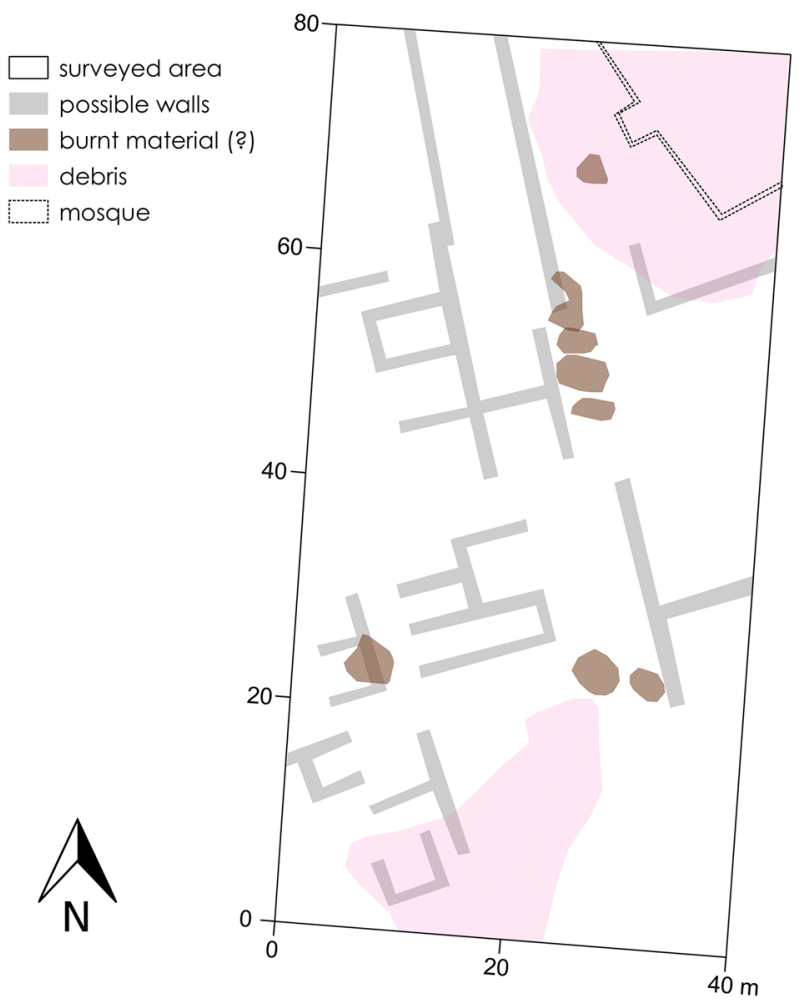

Figure 9. Interpretation of the magnetic anomalies (prepared by Robert Ryndziewicz)

Although the area examined by magnetometry is relatively small, this sample demonstrates the usefulness of the method. It can be assumed that extending the area of the survey will provide crucial information concerning urban planning, as well as the spatial pattern of architecture at Soba (Figure 9). Remains of architecture were recorded on the top and slopes of the mound, as well as in a part of the flat area. This last observation is very important, as it gives an opportunity to study the building distribution on the flat areas between the mounds.

The same study area was documented with a camera suspended under a drone. A series of 228 aerial photographs were taken. Subsequently, the photographs, supplemented by six GPS-measured ground control points, were used to create a 3D model of the surface by means of Agisoft Photoscan software. Three-dimensional data allowed for the creation of a digital elevation model which was transferred to QGIS software (Figure 10), where it could easily be overlapped with the map of anomalies, since both are 


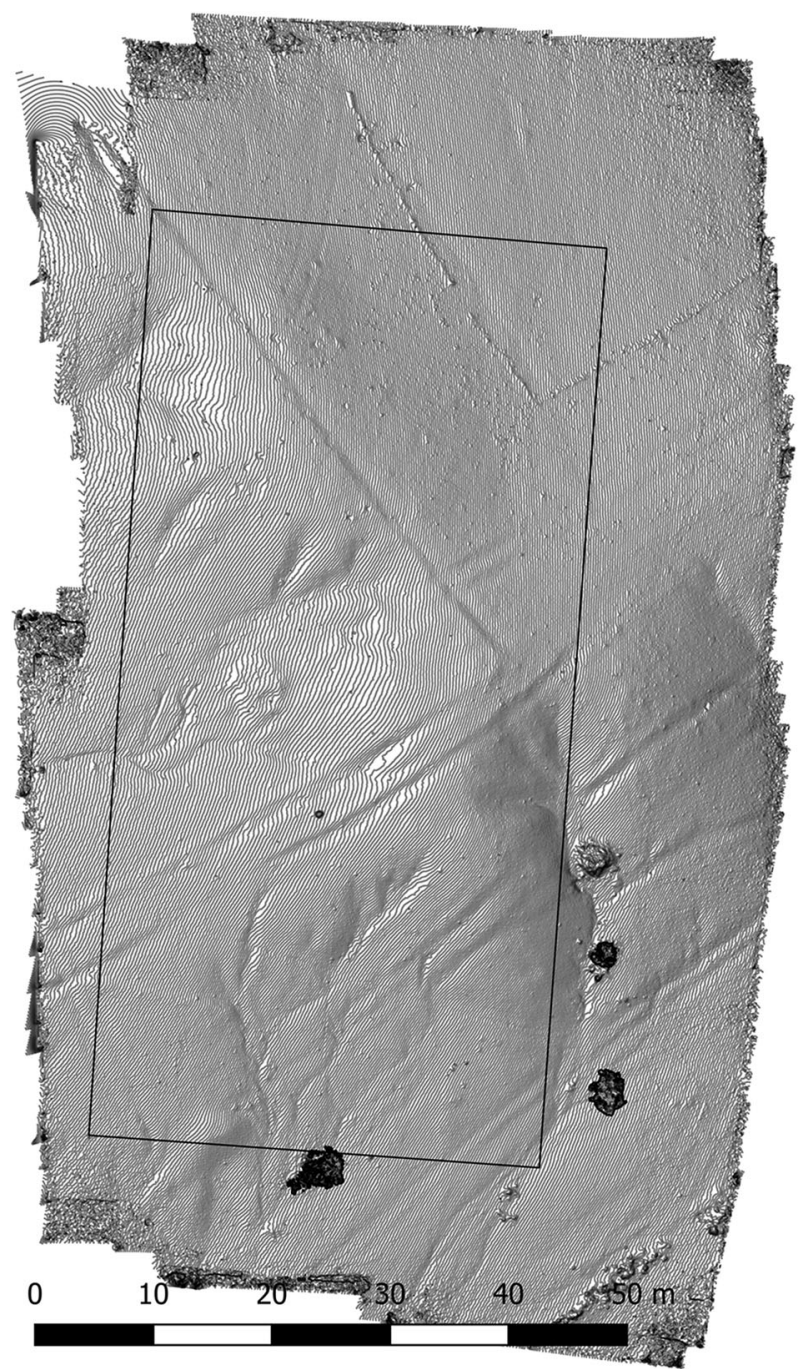

Figure 10. Contour map of the area selected for the geophysical testing (prepared by Mariusz Drzewiecki)

done in the framework of the same coordinate system (WGS 84). This method of documentation provides detailed data on the topography of the area under investigation. It is suitable for tracing and documenting artificial mounds (koms) which are abundant at Soba. At the same time, when overlapped with the magnetic map it enabled a better understanding of the anomalies visible in the results of the geophysical prospection. 
In conclusion, preliminary research conducted in January 2018 gave interesting results, suggesting that a combination of aerial photography and geophysical survey is an approach which can be an efficient method to better understand the archaeological landscape of Soba. A map presenting potentially buried archaeological structures can also become one of the tools in developing protection strategies for the site.

\section{Working with the Community}

Approximately, 220 ha of the medieval capital is now being densely overbuilt or covered with fields, $80 \%$ of the estimated site size. This is a relatively new situation. Analysis conducted in June 2018 of satellite imagery allows for a conclusion that private houses have been built over large parts of the site during this century (Figure 11). When Derek Welsby (personal communication) was conducting his research in the 1980s and 1990s, the area was sparsely populated and the hamlet closest to Soba consisted of a few houses. Today, large amount of people is living in the area.

On the one hand, present-day residents may still remember settling in Soba and may be in possession of artefacts found during various activities, ranging from house construction to common activities in the fields and around their homes. On the other hand, the old Sudan Survey Map of the Khartoum region (sheet 55-B) indicates that already in 1916, there was a small settlement in the area. How far back does it date? Do families living

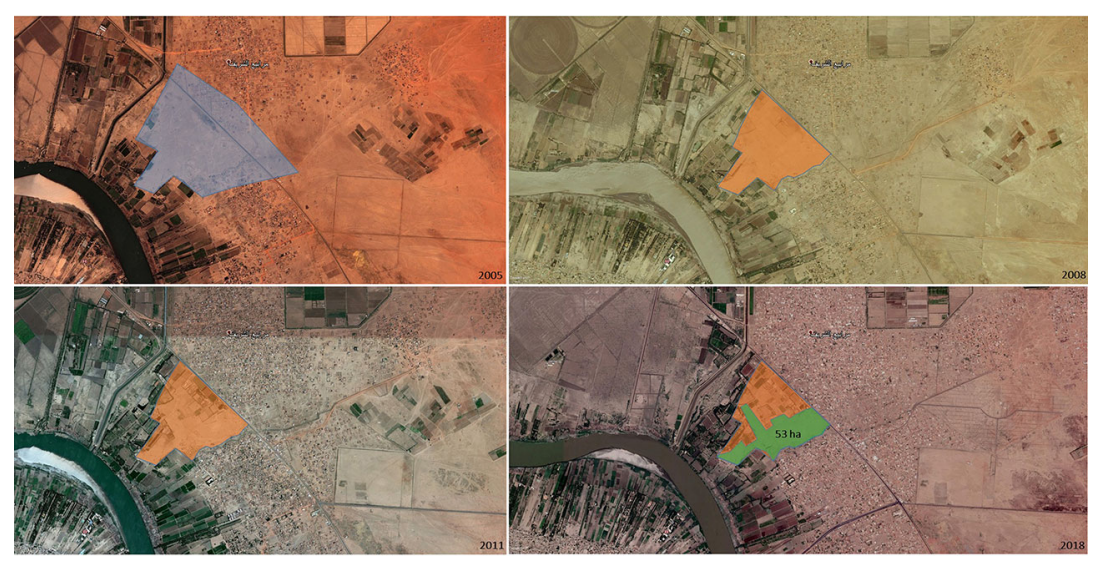

Figure 11. Satellite imagery of Soba in 2005, 2008, 2011 and 2018. Polygon in 2005 image indicates approximate boundaries of the site in 1990s, polygon in the other images show the protected area. The area available for research today is 53 ha (prepared by Mariusz Drzewiecki, background images Google Earth) 
in the oldest part distinguish themselves from more modern residents? Do they keep oral traditions and stories connected with the remains of the capital?

Working in cooperation with the local community is an obvious step in this context. It is important to find common objectives which can constitute goals for the researchers and the residents as well. Both groups should have voices which will express their expectations. Various views taken into consideration and pursued should increase the chances for a long-lasting cooperation. Since the researchers are a small and specialised group, their voice is more homogenous, focused on research, protection of the remains and the work that they are set to conduct. More challenging is to obtain accurate data from a much larger and more varied group of residents. Their approach can depend on multiple factors, connected with their jobs, everyday life and the ways they understand the history of the region.

An interesting case study was made in 2014 and 2015 in the Meroe region, approx. $200 \mathrm{~km}$ north of Soba (Humphris and Bradshaw 2017). There, a quantitative method of questionnaire survey was used to determine local expectations and knowledge about the ruins of Meroe and general understanding of archaeology. This was the first time in Sudan when such a method was used for archaeological heritage studies. Responses were obtained from 215 persons, bringing interesting insights and ideas.

Despite more than a century-long history of archaeological research in Meroe, $13.75 \%$ of interviewees did not know what archaeology is and an additional $14.17 \%$ of respondents did not provide an answer to the question. For the question about the remains of Meroe, $23.74 \%$ of interviewed stated that they did not have any knowledge on the subject. This information seems shocking since the remains of Meroe cover a large area surrounded by modern settlements. The ruins are easily visible and the numerous pyramids are one of the country's symbols, used in nationwide media (television and newspapers).

The results provided by the questionnaire survey at Meroe are paralleled by information collected during a community archaeology project conducted on Mograt Island in 2014-2016 (Tully 2014, 2015; Tully and Näser 2016). Mograt is the largest island on the Nile, located approximately $450 \mathrm{~km}$ north of Soba and $250 \mathrm{~km}$ north of Meroe. The methodology in the project was different from the one implemented in Meroe. It was based on archaeological ethnography (Castañeda and Matthews 2008) and public archaeology (Marshall 2002; Merriman 2004). The approach was more qualitative than quantitative, based on individual interviews and community consultations.

The result revealed a large interest in archaeology and history while at the same time, a lack of information about these issues was recognised. Researchers noted that information about research and the regional past 
are not easily available for the residents. In conclusion, at the end of the project and in consultation with local people, a publication was prepared in English and Arabic bridging identified gaps (Tully and Näser 2016). The target reader was schoolchildren since they constituted the largest age group in the region. The book was printed and distributed in schools and among the residents as well as made available online (http://www.mogratar chaeology.com/sites/default/files/2018-11/MogratBook_WebVersion.pdf, accessed on 13 March 2019).

In the case of research at Soba, creating a comfortable environment for a questionnaire survey will be challenging. The Meroe team had been working for ten seasons at the time when the survey was developed (Humphris and Bradshaw 2017: 204). The residents knew the researchers and at least some of them participated in joint fieldwork. In Soba, we will be the newcomers. At the beginning, we may come across hesitation and lack of trust which might become obstacles in communication. That is why a qualitative approach similar to the methodology used on Mograt Island will be applied for the first seasons of fieldwork at Soba.

To find, contact and identify common ground with the residents, an individual approach with unstructured and semi-structured interviews will be applied. Since our research team will be living in a rented house next to the site, everyday contacts will be a good possibility to talk and to start getting to know the residents. Simultaneously, meetings with local authorities, people's representatives and local associations will be organised. The main agenda of the meetings will be to introduce ourselves and create an open atmosphere for discussion about the remains of Soba. After obtaining permissions, visits to local schools will also be arranged.

In December 2018, a second journey to Soba was made with the aim to test the potential for cooperation with the local community and to document modern activities on the site, using aerial photography. At that time, the local police station was visited and a meeting with the police chief organised. One of the policemen guided us to a modern household on the site, where the most recent accidental discovery was made. The house owner was surprisingly open, and we were shown remains of red brick, mud brick and stone architecture protruding from the ground in the courtyard (Figure 12). We were informed that recently a large pottery vessel was discovered at the place, with bones inside. The landowner stated that it looked like a child interment.

He did not keep the finds but passed them to the local authorities. The policeman, however, did not have any information about the objects. In the future, the residents will be making more of this sort of chance finds. This is why clear and easy guidelines and procedures should be established and promoted in the community and among the authorities, to have as 


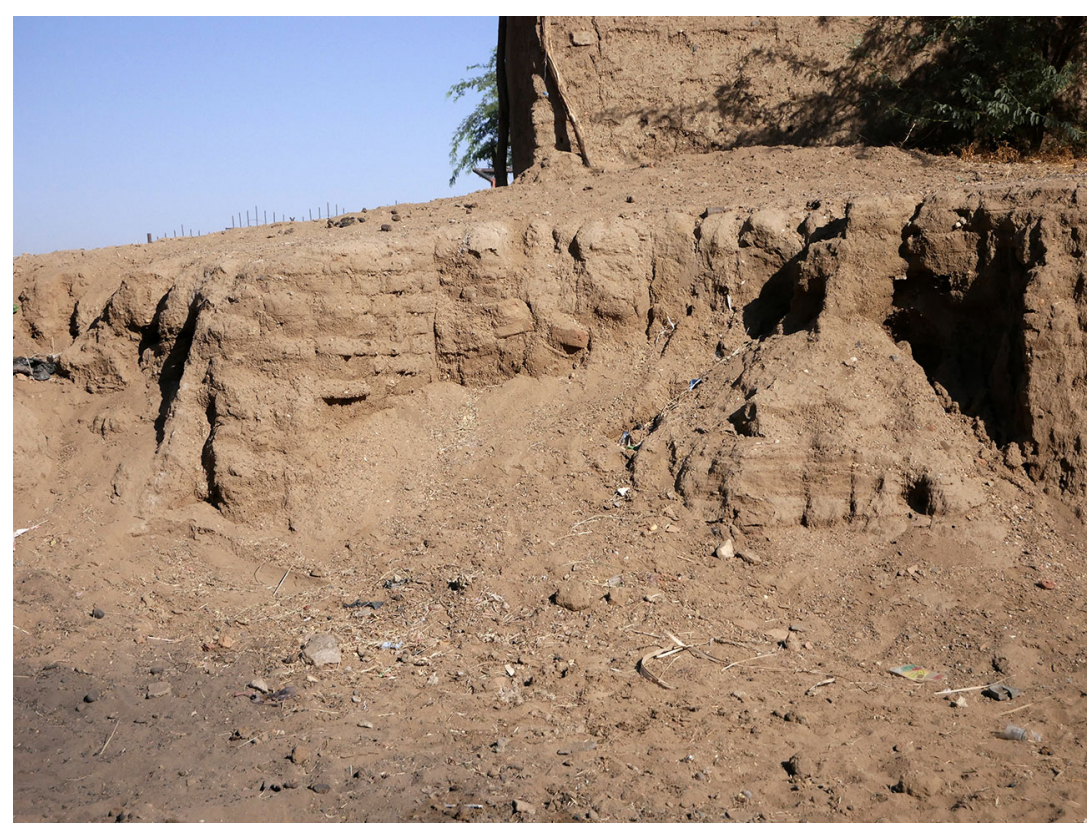

Figure 12. Mud brick architecture in a courtyard of one of the modern houses (photo Mokhtar Maali Alden Mokhtar Hassan)

much information as possible reaching the researchers and authorities responsible for the safekeeping of the site.

A few students and graduates of archaeology from Al-Neelain University (our research partner) live in the Soba area. During the second visit to the site, we were joined by two of them and were able to meet with one other, living approximately $600 \mathrm{~m}$ from the site. They were open for cooperation and offered support in contacting the local community and other residents who are interested in the past. This might be a first step to create a network of local enthusiasts of archaeology and history, who can provide assistance in community outreach activities.

The December visit to Soba was inspiring. It seems that among people living in the area, there are many who are open to cooperation. This refers to residents as well as local authorities. This situation shows that there is still a possibility to make limited studies in areas which are already overbuilt. Since more than the half of the site is now under modern buildings, this is worth considering. A dialogue with the local community about the future perspectives and possibilities of cooperation in research, protection and promotion of local histories should be initiated. For these kinds of 
studies and activities, an independent team, headed by a cultural anthropologist and including archaeologists and interpreters should be created.

\section{A Three-Year Perspective}

With approval from the NCAM, a project proposal was created and submitted to the National Science Centre in Poland. At the end of November 2018, it was accepted for funding. In three years, starting from February 2019, an interdisciplinary team of researchers, Polish and Sudanese, will focus on collecting information on the spatial organisation of the capital of the Kingdom of Alwa.

Archival enquiries will be conducted in the British Museum and the National Corporation for Antiquities and Museums of Sudan, where documentation from previous fieldwork is stored. Four seasons of fieldwork at Soba will be conducted, during which a geophysical prospection, archaeological excavations and survey, as well as ethnological survey and outreach activities, will take place. The project will initiate activities with and among the local community, bringing the voices of researchers and the residents together to lay the foundations for a long-lasting cooperation.

The results of the project will bring unique information on one of the most important archaeological sites in Sudan and will provide data for better protection and management of the site. Studies at this kind of location can bring finds referring to or bridging gaps in general narrations on the history of the Kingdom of Alwa and the much wider region of North East Africa and the Near East.

The results of the project will allow for closer comparison between the medieval capitals of Nubia and other metropolis of the Sahelian kingdoms. Tracking similarities and differences in the spatial organisation of African capitals can bring insights into transregional contacts and local traditions. The issue will also be illuminated through detailed analysis of the small finds.

Previous research in Soba studied in detail only 1\% of the site. It would be unwise to state that this three-year project will cover the remaining $99 \%$. Our methodology is designed to obtain precise information on the general characteristics of various areas of Soba. This will lay the foundations for future projects with and among residents, allowing prospective teams to choose and focus on specific districts of the capital, such as production sites, religious centres, domestic architecture, royal complexes, trade routes, as well as various issues connected with life in the medieval capital. 


\section{Acknowledgements}

We would like to thank Dr Abdelrahman Ali Mohammed (General Director of the NCAM) and Dr El-Hassan Ahmed Mohamed (Director of Foreign Missions Section of the NCAM) for supporting our work. We also would like to thank Tomasz Herbich for making the geophysical survey possible and Dr Artur Obłuski for support in obtaining research concession. We are grateful to Dr Isabella Welsby Sjöström and Dr Derek Anthony Welsby for extremely accurate comments and suggestions. The research in Soba is funded by the National Science Centre, Poland (Grant Number UMO-2018/29/B/HS3/02533).

\section{Compliance with Ethical Standards}

Conflict of interest The authors declare that they have no conflict of interest.

\section{Open Access}

This article is distributed under the terms of the Creative Commons Attribution 4.0 International License (http://creativecommons.org/licenses/ by/4.0/), which permits unrestricted use, distribution, and reproduction in any medium, provided you give appropriate credit to the original author(s) and the source, provide a link to the Creative Commons license, and indicate if changes were made.

\section{References}

Abdel Rahman, A. M.

(2000). Rescue Excavations at Soba East. Sudan \& Nubia, 4, 27-31.

Budge, E. A. W.

(1907). The Egyptian Sudan (Vol. 2). Clerkenwell: Gilbert and Rivington LTD., St. John's House.

Cailliaud, F.

(1826). Voyage a Méroé, au Fleuve Blanc, au-delà de Fazoql, 4 vols. Paris: L’Imprimerie Royale.

Castañeda, Q., \& Matthews, C. N. (Eds.).

(2008). Ethnographic archaeologies: Reflection on stakeholders and archaeological practices. Plymouth: AltaMira Press. 
David, A., Linford, N., \& Linford, P.

(2008). Geophysical survey in archaeological field evaluation (2nd ed.). Swindon: English Heritage.

Drzewiecki, M., \& Ryndziewicz, R.

(2018). Trial geophysical survey in Soba East conducted on 26th of January 2018. In Drzewiecki, M., Cedro, A., Rączkowski, W. and Ryndziewicz, R. (eds.), Expedition to Hosh el-Kab, Abu Nafisa, and Umm Marrahi forts, (pp. 33-34) Omdurman. https://doi.org/10.13140/rg.2.2.30734.259 21.

Dümichen, J.

(1894). Zur Geographie des Alten Ägypten. Leipzig: J.C. Hinrichs'sche Buchhandlung.

Freestone, I., \& Stapleton, C.

(1998). The metalworking debris. In Welsby, D.A. (ed.), Soba II. Renewed excavations within the metropolis of the Kingdom of Alwa in Central Sudan (Memoirs of the British Institute in Eastern Africa number 15), London: British Institute in Eastern Africa, pp. 81-83.

Herbich, T.

(2019). Efficiency of the magnetic method in surveying desert sites in Egypt and Sudan: Case studies. In R. Persico, S. Piro, \& N. Linford (Eds.), Innovation in near-surface geophysics (pp. 195-251). Amsterdam: Elsevier. http s://doi.org/10.1016/b978-0-12-812429-1.00007-6.

Hillelson, S.

(1933). David Reubeni, an early visitor to Sennar. Sudan Notes and Records, 16(1), 55-66.

Humphris, J., \& Bradshaw, R.

(2017). Understanding 'the community' before community archaeology: A case study from Sudan. Journal of Community Archaeology \& Heritage, 4(3), 203-217. https://doi.org/10.1080/20518196.2017.1345364.

Lejean, G.

(1865). Voyage aux deux Nils (Nubie, Kordofan, Soudan Oriental). Paris: L. Hachette, Libraires-Éditeur's.

Lepsius, K. R.

(1853). Letters from Egypt, Ethiopia, and the Peninsula of Sinai. London: Henry G. Bohn.

(1913). Denkmäler aus Aegypten und Aethiopien. Fünfter Band: Nubien, Hammamat, Sinai, Syrien und Europäische museen. J.C. Hinrichs'sche Buchhandlung, Leipzig.

Marshall, Y.

(2002). What is community archaeology? World Archaeology, 342, 211-219. 
Merriman, N. (Ed.).

(2004). Public Archaeology. London: Routledge.

Mohamed Ali, M. A., Herbich, T., Grzymski, K., \& Hobbs, R.

(2012). Magnetic gradient and electrical tomography surveys in Meroe, the capital city of Kush Kingdom. Sudan. Archaeological Prospection, 19(1), 5968 .

Monneret de Villard, U.

(1935). La Nubia Medioevale (Vol. 2). Le Caire: Service des Antiquites de l'Egypte.

Shinnie, P.L.

(1961). Excavations at Soba (Sudan Antiquities Service Occasional Papers no. 3), Khartoum: Sudan Antiquity Service.

Somers Clarke, G.

(1912). Christian antiquities in the Nile Valley. A Contribution towards the study of the ancient churches. Oxford: Clarendon Press.

Tully, G.

(2014). Community archaeology on Mograt Island: Sharing spaces, understanding sites, MittSAG. Der antike Sudan, 25, 155-160.

(2015). Community archaeology in Sudan: Discovering Mograt Island together, MittSAG. Der antike Sudan, 26, 201-204.

Tully, G., \& Näser, C.

(2016). Discovering Mograt Island together. London: Golden House Publications.

Ullrich, B., \& Wolf, P.

(2015). Hamadab near Meroe (Sudan): results of multi-technique geophysical surveys. Archaeologia Polona, 53, 392-395.

Van Gerven Oei V.W.J.

(2018). Alwan Nubian and alphabetic writing in the Medieval Sudan. In 14th International conference for Nubian studies september 10 to 15, 2018 (Book of Abstracts), Paris: Musée du Louvre, Sorbonne Université, pp. 109.

Vantini, G.

(1975). Oriental sources concerning Nubia. Heidelberg: The Polish Academy of Sciences and Heidelberger Akademie der Wissenschaften.

Ward, J.

(1905). Our Sudan, its pyramids and progress. London: J. Murray.

Welsby, D.A.

(1998). Soba II. Renewed excavations within the metropolis of the Kingdom of Alwa in Central Sudan (Memoirs of the British Institute in Eastern Africa number 15). London: British Institute in Eastern Africa. 
(2002). The medieval kingdoms of Nubia. Pagans, Christians and Muslims along the Middle Nile. London: The British Museum Press.

(2004). Soba East. In D. A. Welsby \& J. R. Anderson (Eds.), Sudan ancient treasures: An exhibition of recent discoveries from the Sudan National Museum (pp. 197-237). London: The British Museum Press.

Welsby, D.A., \& Daniels, C.M.

(1991). Soba. Archaeological research at a medieval capital on the Blue Nile (Memoirs of the British Institute in Eastern Africa number 12). London: Thames \& Hudson Ltd.

Publisher's Note Springer Nature remains neutral with regard to jurisdictional claims in published maps and institutional affiliations. 